\title{
Fortification of Beer with Extracts of the Selected Czech Medicinal Herbs and Plants
}

\author{
Helena Pluháčková ${ }^{1}$, Tomáš Gregor ${ }^{1}$, Rastislav Boško ${ }^{1,2}$, Sylvie Běláková2, Zdeněk Svoboda ${ }^{2}$, \\ Karolína Benešová ${ }^{2}$ \\ 1 Department of Crop Science, Breeding and Plant Medicine, \\ Mendel University in Brno Zemědělská 1, 61300 Brno, \\ Czech Republic \\ 2 Research Institute of Brewing and Malting, \\ Mostecká 7, 61400 Brno, Czech Republic \\ *corresponding author: helena.pluhackova@mendelu.cz
}

\begin{abstract}
This study investigated the possibilities of fortification of beer with various herbal extracts. The aim was to fortify beer with natural substances that have favourable effects on consumers' health. The tested beers were enriched with ethanol extracts of medicinal herbs (ribwort plantain, small leaved linden, purple coneflower, chamomile, sage) so that the sensory characters of the supplemented herbal extract created only an accompanying perception and the malt and hop flavour of beer was preserved. In the enriched beers, the contents of the selected phenolic substances and important essential oils were determined and sensory evaluation was performed. The content of phenolic substances increased the most in beer with linden $(42.46 \mathrm{mg} / \mathrm{l})$ and plantain $(37.5 \mathrm{mg} / \mathrm{l})$ extracts, approximately four times compared to the original beer $(8.11 \mathrm{mg} / \mathrm{l})$. Beer with sage and chamomile extract achieved the best sensory assessment, with components of essential oils added in units of $\mathrm{ng} / \mathrm{l}$ of beer.
\end{abstract}

Key words: beer, herbal extract, phenolic substances, essential oils

\section{Introduction}

Beer is one of the oldest man-made and most frequently consumed beverages worldwide (Kawa-Rygielska et al., 2019). This beverage with low alcohol content is typically made from cereal malt, water and hops by fermentation using the brewery yeast (Basařová et al., 2011). It contains up to two thousand different substances beneficial for health: carbohydrates, proteins, vitamins, minerals, soluble fibre and polyphenolic compounds (Sohrabvandi et al., 2012; Olšovská et al., 2014). Approximately 70-80\% of polyphenolic substances in beer come from malt, the remaining 20-30\% from hops (Dvořáková at al., 2010; Wannenmacher et al., 2018). Besides the polyphenolic substances which affect beer palatefulness, hops give beer hop resins which add the beer bitter taste and essential oils providing a characteristic aroma (Kosař et al., 2000; Basařová et al., 2011).
Hops has been used for hopping beer since the end of antiquity (Basařová et al., 2010). In the past, therefore, beer was brewed without hops and various herbs were added to flavour it.

Ancient brewers affected beer sensory characters, its stability and health safety by adding herbs. The herbs used differed mainly according to the territory where the beer was brewed (Hornsey, 2003). These herbs included, for example, sage, wormwood, peppermint, cinnamon, anise, juniper, boxwood, pepper, ginger, bay leaf, but also spruce needles, oak bark, alder leaves, honey, and beet seed. The Celts are said to have added extracts from alkaloid-containing plants to beer, such as Strychnos nux-vomica (strychnine), poppy (opium) or Claviceps purpurea (sklerocium, ergot) (Hornsey, 2003; Basařová et al., 2011). About two thousand years ago, gruit (grut, gruut), an herb 
mixture for a bitter taste of beer was created; it was mainly used in Northwestern Europe. This mixture consisted of sweet gale, mugwort, yarrow, ground ivy, horehound, and Calluna heather. According to other sources, other adjunct herbs also included juniper berries, ginger, caraway seed, aniseed, nutmeg, cinnamon and mint (Klemp, 2016). The term gruit is also currently used for beer produced through a top-fermentation process (Buhner, 2002). Today, gruit refers to herbal craft beer and is currently produced, for example, in Belgium (Nerad, 2018) or France and also in the Czech Republic - for example, in the brewery in Lobeč u Mšena where they add yarrow, wormwood, and blackberry leaves to beer (Petr, 2016). Herbal beers form a subgroup of flavoured beers; they are not considered a separate type, category or style (Government Decree No. 248/2018 Coll.). Herbs, sometimes supplemented with fruits and other ingredients, are added in two ways: either during mashing with decoction (which is actually similar to a classic wort-boiling), or during the main fermentation or final fermentation by maceration or leaching. In both cases, the flowers of the herbs and their stems and roots are used, and processed fresh and dried plants are added to the beer. Herbal ingredients can interestingly change the taste, aroma, colour, and sharpness of this beverage. Herbal beers are produced in a number of Czech breweries (Gembala, 2019). Other plants, such as cherries (Kawa-Rygielska et al., 2019), exotic fruits (Zapata et al., 2019) or sweet potatoes (Humia et al., 2019) are also used to achieve a non-traditional beer taste. Besides an increased content of polyphenolic substances, these beers are also characterized by higher antioxidant activity.

The aim of this study was firstly to enrich the model beer with extracts of Czech medicine herbs and plants, further to determine the content of the selected phenolic substances and important essential oils in the fortified beer and, finally, based on the sensory evaluation, to select the beers acceptable for consumers that would retain their malt and hop taste base and in which the added herbal extract would create only an accompanying pleasant perception.

\section{Material and Methods}

\subsection{Beers}

A model beer (pale unfiltered draft Pilsner-type beer) for fortification with herbal extracts was prepared in a microbrewery of Mendel University in Brno.

\subsection{Herbal extracts}

Medicinal herbs that are common in MACP (Medicinal, Aromatic and Culinary Plants) cultivation practice (medicinal, aromatic and spice plants) were selected. The plants came from the Czech Republic, harvest 2015. The following herbs were used for the production of alcoholic extracts: leaves of ribwort plantain (Plantago lanceolata L.), blossoms of small leaved linden (Tilia cordata Mill.), root of purple coneflower (Echinacea purpurea L.), blossoms of German chamomile (Matricaria Chamomilla L.), and leaves of sage (Salvia officinalis L.).

The plant material was macerated in 20, 40 and $60 \%$ (v/v) solution of ethanol. Maceration took place in glass jars in the dark for 30 days.

\subsection{Fortification of beers}

Prior to the fortification itself, the overall subjective sensory impression from the given amount of extract in beer was assessed (Pluháčková et al., 2019). The selected extracts were macerated in $60 \%$ alcohol. The amount of extract in the beer was always chosen so that the beer retained its malt and hop flavour base, and the sensory properties of the herb created only an accompanying perception of this beer. Table 1 shows the volumes of the individual herbal extracts that were added to the beer.

Table 1 Volumes of the herbal extracts added to beer

\begin{tabular}{|l|c|c|}
\hline Beer_denotation & Ethanol extract (60\%) & $\begin{array}{c}\text { Extract } \\
\text { (ml/l of beer) }\end{array}$ \\
\hline Beer_0 & - & - \\
\hline Beer_RL & Ribwort plantain leaves & 10 \\
\hline Beer_LB & $\begin{array}{c}\text { Small leaved linden } \\
\text { blossoms }\end{array}$ & 40 \\
\hline Beer_PC & Purple coneflower root & 14 \\
\hline Beer_CB & Chamomile blossoms & 14 \\
\hline Beer_SL & Sage leaves & 14 \\
\hline
\end{tabular}

The beer was filled using a $\mathrm{CO}_{2}$-driven bottling mechanism into 1-liter PET bottles. The exact volume of the given extract was added to the draft beer (Table 1). The beer samples were stored for seven days without exposure to sunlight at a temperature of $6^{\circ} \mathrm{C}$.

The contents of the selected phenolic substances were determined in beers enriched with the extracts from ribwort, linden and purple coneflower, and main components of essential oil were assessed in beers enriched with the extracts from chamomile and sage. Sensory analysis of beers was performed.

\subsection{Determination of the phenolic substance content}

Standards of phenolic substances with a purity of at least 94\% (Sigma-Aldrich, USA): chlorogenic acid; caffeic acid; ferulic acid; verbascoside; rutin; quercetin; kaempherol; 
hyperoside; isovercitroside; tiliroside, chemicals: acetonitrile, methanol, formic acid (Sigma-Aldrich, USA), deionized water.

$1 \mathrm{ml}$ of defoamed beer was diluted with methanol in a ratio of 1:1. The samples were then filtered through a nylon microfilter $(0.45 \mu \mathrm{m})$ into vials.

The Waters Acquity UPLC 2996 liquid chromatograph with a PDA detector was used to determine selected phenolic substances in fortified beers. Separation was performed on a Phenomenex Luna Omega chromatographic column $(1.6 \mu \mathrm{m} \mathrm{C} 18,100 \AA, 100 \times 2.1 \mathrm{~mm})$ using gradient elution. Mobile phase A (DI $\mathrm{H}_{2} \mathrm{O}, 2 \% \mathrm{ACN}, 0.3 \% \mathrm{HCOOH}$ ), mobile phase $\mathrm{B}(\mathrm{ACN}, 0.3 \% \mathrm{HCOOH})$, injection volume $1 \mu \mathrm{l}$, mobile phase flow $0.3 \mathrm{ml} / \mathrm{min}$, temperature $30{ }^{\circ} \mathrm{C}$. Gradient elution conditions: 0 min - 15\% B; 2 min - 15\% B; 8 min - 45\% B; 10 min - 80\% B; 12 min - 15\% B. UV detection was performed at wavelengths of 250 and $300 \mathrm{~nm}$ depending on the absorption maximum of individual analytes (Běláková et al., 2010; Arigó et al., 2018).

\subsection{Determination of herbal essential oils components}

Standards (Sigma-Aldrich, USA): p-cymene, limonene, farnesene, $\alpha$-bisabolol, bisabolol oxide A, cineole, borneol, camphor, thujone, bornyl acetate, hexane solvent (Sigma-Aldrich, USA).

A Trace GC Ultra Finnigan gas chromatograph combined with a Trace DSQ Thermo Finnigan mass detector was employed to determine the chamomile and sage content substances. The separation was performed on a SLB-5MS capillary column $(60 \mathrm{~m} \times 0.25 \mathrm{~mm} \times 0.25 \mu \mathrm{m}$; Supelco, USA), the carrier gas was helium. The mass detector operated in FULL scan $(m / z$ 20-450) with positive electron impact (EI) ionization. The identification of the monitored analytes was performed on the basis of comparison of retention time and specific mass spectra with standards. For the GC-MS determination of contents of chamomile and sage essential oils, the essential oils were appropriately diluted with hexane, the injection volume in the analysis was $1 \mu \mathrm{l}$ of the diluted sample.

The HS/SPME technique with DVB/CAR/PDMS fibre was used for the GC-MS determination of chamomile and sage content substances in herbal extracts and fortified beers. Samples of herbal extracts and fortified beers were appropriately diluted in $5 \mathrm{ml}$ of deionized water into $10 \mathrm{ml}$ vials and these were closed with a septum cap. HS/SPME extraction was performed for 20 minutes at $60^{\circ} \mathrm{C}$, desorption in a GC injector was conducted for 3 minutes at $250^{\circ} \mathrm{C}$.

\subsection{Sensory evaluation of beer with herbal extracts}

During sensory tests, which were conducted at the Institute of Food Technology, Faculty of Agriculture MENDELU in Brno, the intensity of odour, taste, palatefulness, sharpness, bitterness and overall subjective impression were evaluated using a 5-point scale based on the "Circle Scheme" according to Beerweb 2018 (Beerweb, 2018).

\section{Results and Discussion}

\subsection{Beer without extract}

Phenolic chlorogenic acids $(2.39 \mathrm{mg} / \mathrm{l})$, caffeic acid $(0.77 \mathrm{mg} / \mathrm{l})$, ferulic acid (4.25 mg/l) and flavonoid kaempferol $(0.77 \mathrm{mg} / \mathrm{l})$ were determined in beer without added extract (Table $2 \mathrm{a}$ ).

\subsection{Beer_RL}

The content of chlorogenic acid in beer with the addition of extract of ribwort plantain was almost double $(4.32 \mathrm{mg} / \mathrm{l})$. Chlorogenic acid contributes to the neutralization of free radicals coming from the environment or food (Clifford, 2003), it also increases the solubility of caffeine and is an important taste modulator (Zhao et al., 2011). The content of caffeic acid (1.87 mg/l), which can suppress the production of aflatoxin B1, more than doubled (Paster et al., 1988). Further, the flavonoid verbascoside (19.72 mg/l) was determined, this phenylpropane flavonoid of caffeic acid, like other flavonoids, has antioxidant, antimicrobial and antihypertensive effects. Furthermore, the flavonoid rutin $(5.3 \mathrm{mg} / \mathrm{l})$ was detected: it acts against problems with fragility of vascular capillaries, hemorrhage, hypertension, allergy, as an adjuvant in infectious diseases and it also accelerates wound healing. It lowers liver cholesterol, dilutes the blood and is an important antioxidant (Suchý, 1989; Tomko et al., 1999). Another flavonoid found was kaempferol. The total content of phenolic substances in beer with ribwort was $37.5 \mathrm{mg} / \mathrm{l}$ compared to beer without extract, where the phenolic substance content was only $8.11 \mathrm{mg} / \mathrm{l}$ (Table 2a).

In general, ribwort plantain leaves contain, among others, polysaccharides, glycosides, aucubin, flavonoids, and phenolic acids, mucilages, tannins, coumarins, terpenes, and traces of alkaloids (Jahodár, 2010). They are used internally mainly to reduce cough and loosen and remove mucus from the airways, the herb has anti-inflammatory and antibiotic effects.

\subsection{Beer_LB}

The beer with linden had an almost five times higher content of chlorogenic acid (10.33 mg/l), in addition, rutin was also found $(2.55 \mathrm{mg} / \mathrm{l})$. Further, isoquercitroside $(7.83 \mathrm{mg} / \mathrm{l})$, which acts against stress, cardiovascular disease, diabetes and allergic reactions, was also determined in linden beer (Valentová et al., 2014). A specific substance typical of linden is the flavonoid tiliroside. Tiliroside is im- 
portant for the treatment of inflammatory diseases of the respiratory tract and rhinitis (Grochovski et al., 2018). It was found in beer in the amount of $15.23 \mathrm{mg} / \mathrm{l}$. The total content of phenolic substances in the linden beer was $42.46 \mathrm{mg} / \mathrm{l}$ in comparison with the beer without extract with the phenolic substance content of only $8.11 \mathrm{mg} / \mathrm{l}$.

The small leaved linden blossoms contain mainly mucilaginous substances, tannins, flavone glycosides, flavonoids, organic acids, essential oils, saponins, and phytosterols. Active substances in the form of tea have a wide range of uses as they have spasmolytic, sedative and diaphoretic effects, regulate the activity of the digestive system and lower blood pressure (Jahodár, 2010).

\subsection{Beer_PC}

Beer with purple coneflower contained rutin $(2.2 \mathrm{mg} / \mathrm{l})$, kaempferol $(0.76 \mathrm{mg} / \mathrm{l})$ and about $23 \%$ more ferulic acid; this acid has a wide range of uses in the treatment of various diseases, such as diabetes, neurodegenerative or cardiovascular diseases (Park et al., 2018). The content of other substances was comparable to beer without extract. The total content of phenolic substances in beer with coneflower was $11.08 \mathrm{mg} / \mathrm{l}$, which was slightly higher than in the original beer $(8.11 \mathrm{mg} / \mathrm{l})$.

Purple coneflower contains essential oils, resins, polysaccharides, flavonoids and phenolic acids, echinacosides, and tannins. The coneflower improves immunity, metabolism, it has disinfectant, anti-inflammatory and antibiotic effects (Hudson, 2009; Vimalanthan et al., 2009).

\subsection{Beer_CB}

The main constituents of chamomile are essential oils, sesquiterpene bisabolol, flavonoids, choline, mucus, bitters. The presence of 109 active substances was detected. The use of chamomile is versatile. Above all, it is a strong antispasmodic, but it also has a sedative effect on the psyche, antimicrobial and analgesic effects (European Scientific Cooperative on Phytotherapy, 2003;
Poštulková, 2018). Ethanol chamomile extract affects positively memory and may be useful in patients with Alzheimer's disease as well as behavioural disorders (Alibabaei et al., 2014). In chamomile essential oil, one of the important components is bisabolol, more precisely $\alpha-(-)$-bisabolol. It is used for its calming, regenerating, anti-inflammatory and antimicrobial effects (Pongoue Kamatou and Viljoen, 2009). Its contents are high, especially in the case of chamomile chemotypes grown in the Czech Republic (designation of the country of origin "Chamomila Bohemica"). The beer with chamomile contained $2.8 \mathrm{mg} / \mathrm{l}$ of $\alpha$-bisabolol, other important essential oil components, i.e. p-cymene, limonene and farnesene, were found in the amount of $2-3.7 \mathrm{ng} / \mathrm{l}$, while the amount of these compounds in the original beer were below LOD.

\subsection{Beer_SL}

Sage leaf is used for its anti-inflammatory, antiviral and antibacterial effects, it prevents diarrhoea. It reduces sweating, helps with stomach, intestinal and gallbladder problems and bloating. It is used as a remedy for inflammation of the oral cavity. It contains mainly essential oils, tannins, bitters and flavonoids (Lánská, 1999; Ghorbani and Esmaeilizadeh, 2017). Sage essential oil contains a mixture of thujone, camphor, cineole, and borneol. Sage extract contained a larger amount of camphor, which has been shown to have an anti-inflammatory effect (Jahodář, 2010). In the beer with the sage extract, the most represented essential oil components were camphor $(0.42 \mathrm{mg} / \mathrm{l})$ and thujone $(0.39 \mathrm{mg} / \mathrm{l})$. Contents of cineole and bornyl acetate were $0.09 \mathrm{mg} / \mathrm{l}$ and $0.02 \mathrm{mg} / \mathrm{l}$, respectively.

The total antioxidant activity of these beers was not determined; however, due to the increased content of substances with antioxidant effect detected, its significant increase can be assumed (Dordevič et al., 2016).

Table 2a Results of the determination of the selected phenolic substances ( $\mathrm{mg} / \mathrm{l}$ ) in fortified beers

\begin{tabular}{|c|c|c|c|c|c|c|c|c|c|c|}
\hline 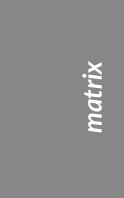 & 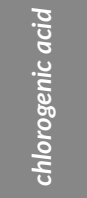 & $\begin{array}{l}\frac{7}{8} \\
\frac{u}{\pi} \\
\frac{.0}{5}\end{array}$ & 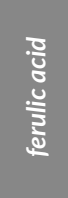 & 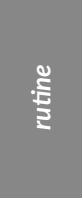 & 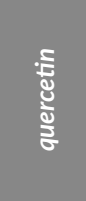 & 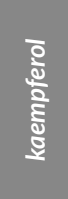 & $\begin{array}{l}\frac{0}{\bar{c}} \\
\frac{0}{0} \\
\frac{0}{2}\end{array}$ & 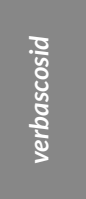 & $\begin{array}{l}\frac{0}{5} \\
\frac{5}{0} \\
\frac{5}{0} \\
\frac{3}{3} \\
\frac{0}{0}\end{array}$ & 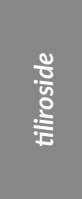 \\
\hline Beer_0 & 2.39 & 0.77 & 4.25 & $<$ LOD & $<L O D$ & 0.7 & $<L O D$ & $<$ LOD & $<$ LOD & $<L O D$ \\
\hline Beer_RL & 4.32 & 1.87 & 4.68 & 5.30 & $<L O D$ & 1.61 & - & 19.72 & - & - \\
\hline Beer_LB & 10.33 & 0.55 & 4.36 & 2.55 & $<L O D$ & 0.68 & $<L O D$ & - & 7.83 & 15.23 \\
\hline Beer_PC & 2.17 & 0.62 & 5.33 & 2.20 & $<L O D$ & 0.76 & $<L O D$ & - & $<L O D$ & - \\
\hline
\end{tabular}


Table $2 \mathrm{~b}$ Results of the determination of the significant components of essential oils (mg/l) in fortified beers

\begin{tabular}{|c|c|c|c|c|c|c|c|c|c|c|}
\hline 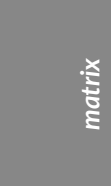 & 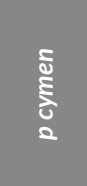 & 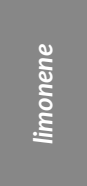 & 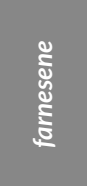 & $\begin{array}{l}\frac{0}{8} \\
\frac{0}{0} \\
\frac{n}{2} \\
\dot{0}\end{array}$ & 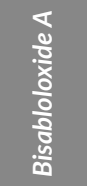 & $\begin{array}{l}\frac{0}{8} \\
\stackrel{\Xi}{0}\end{array}$ & $\begin{array}{l}\overline{8} \\
\stackrel{\Xi}{0} \\
8\end{array}$ & $\frac{\text { 흘 }}{\frac{1}{\Xi}}$ & 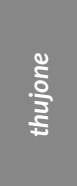 & 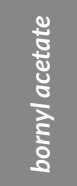 \\
\hline Beer_0 & $<$ LOD & $<$ LOD & $<$ LOD & $<$ LOD & $<$ LOD & $<$ LOD & $<$ LOD & $<$ LOD & $<$ LOD & $<L O D$ \\
\hline Beer_CB & $3 \cdot 10^{-4}$ & $2 \cdot 10^{-4}$ & $4 \cdot 10^{-3}$ & 2.83 & $<$ LOD & $<$ LOD & $<$ LOD & $<$ LOD & $<L O D$ & $<L O D$ \\
\hline Beer_SL & $<$ LOD & $<$ LOD & $<$ LOD & $<$ LOD & $<$ LOD & 0.09 & $<L O D$ & 0.42 & 0.39 & 0.02 \\
\hline
\end{tabular}

\subsection{Sensory tests}

The evaluation of beers using the degustation Circle Scheme is graphically shown in Figure 1.

The evaluation showed that the aroma and taste were ranked the best in the beer with sage extract; aroma and taste of the beer with the addition of coneflower came second. As for the palatefulness, beers with coneflower achieved the highest score, while beers with the addition of chamomile were the worst. Bitterness intensity was rated best in beer with linden, sage and coneflower, while the beer with ribwort plantain was the worst. The ratings of sharpness of all beers were comparable. The assessment according to the overall impression rated best the beer with the addition of sage, beers with extracts from chamomile, linden, plantain, and coneflower followed.

As evident from the above mentioned, even a low concentration of herbal substances, as in the case of sage extract, affected significantly the aroma, taste and thus the overall impression of the final beer.

\section{CONCLUSION}

The purpose of this study was to fortify the beer with natural herbal and plant substances. It is evident from the results that the addition of extracts increased the content namely of polyphenols and phenolic acids (more than four times in linden and plantain beer), essential oils and other substances. Although the total antioxidant activity of these beers was not measured, considering the increased content of substances with the antioxidant effect detected, its significant increase can be assumed. These beers can also be used, due to their contents of vitamins, polyphenols, flavonoids, alkaloids, and other bioactive substances, for the replenishment of these health beneficial substances in beer. Herbs should harmoniously accompany the taste of beer; therefore, herbal extracts should be used only in small amounts to avoid overlapping of strong flavours.

Figure 1 Sensory assessment of beers with the addition of herbal extracts

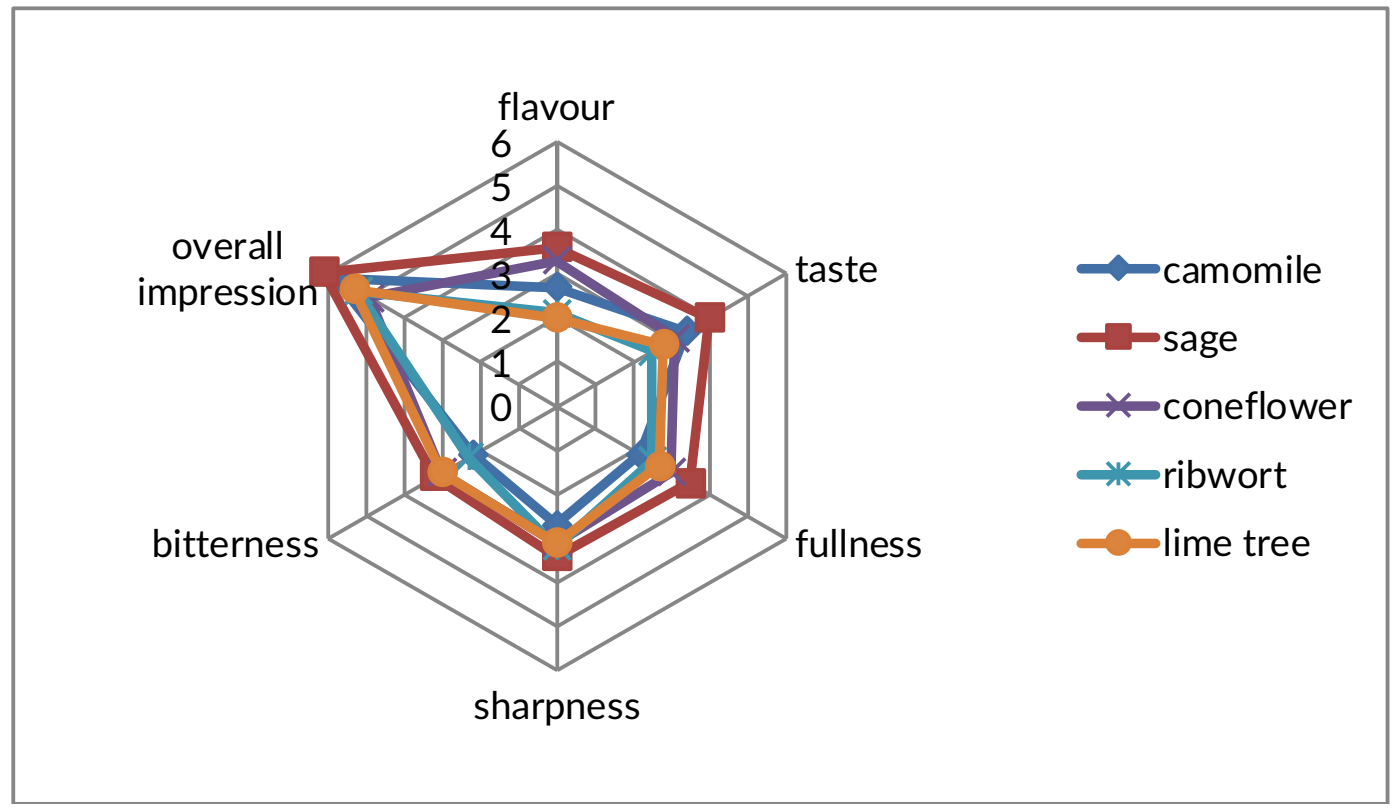




\section{ACKNOWLEDGEMENT}

This study was carried out within solution of the project TAČR TE02000177 Centre for innovative use and strengthening of competitiveness of Czech brewery raw materials and products, and with the institutional support MZE-R01918 provided by the Ministry of Agriculture of the Czech Republic.

\section{REFERENCES}

Alibabaei, Z., Rabiei Z., Rahnama, S., Mokhtari, S., Rafieian-kopaei, M. (2014). Matricaria Chamomilla extract demonstrates antioxidant properties against elevated rat brain oxidative status induced by amnestic dose of scopolamine. Biomedicine \& Aging Pathology, 4(4), 355-360. https://doi.org/10.1016/j.biomag.2014.07.003

Arigó, A. Česla, P., Šilarová, P., Calabro, M., Česlová, L. (2018). Development of extraction method for characterization of free and bonded polyphenols in barley (Hordeum vulgare L.) grown in Czech Republic using liquid chromatography-tandem mass spectrometry. Food Chemistry, 245, 829-837. https://doi.org/10.1016/j.foodchem.2017.11.101

Basařová, G., Hlaváček, I., Basař, P., Hlaváček, J. (2011). České pivo (Czech Beer). Havlíček Brain Team, Př́bram, 3rd supplemented edition. ISBN 978-80-87109-25-0

Basařová, G., Šavel, J., Basař, P., Lejsek, K. (2010). Pivovarství. Teorie a praxe výroby piva. VŠCHT, Praha, 863 p. ISBN 978-80-7080-734-7

Beerweb (2018). Beer tasting. Beer tasting flavor wheel. In: beerweb.cz [online]. [cit. 2020-03-20]. Available in Czech from: https://beerweb.cz/novinky/degustace-piva

Běláková, S., Benešová, K., Mikulíková, R., Svoboda, Z. (2010). Monitoring of Changes of Ferulic Acid Content in Brewing Materials Using the UPLC with PDA Detector. Kvasný průmysl, 56(6), 266-269. https:// doi.org/10.18832/kp2010032

Buhner, S.H. (2002). Sacred and Herbal Healing Beers: The Secrets of Ancient Fermentation. Volvox Globator. ISBN 80-7207-484-9.

Clifford, M.N. (2003). Methods in Polyphenol Analysis. Santos-Buelga C. (ed.) Royal Society of Chemistry, Cambridge. ISBN 0-85404-580-5

Dorděvič, S., Popovič, D., Despotovič, S., Veljovič, M., Atanackovič, M., Cvejič, J., Nedovič, V., Leskošek-Čukalovič, I. (2018). Extracts of medicinal plants as functional beer additives. Chemical Industry \& Chemical Engineering Quarterly, 22(3), 301-308. https://doi.org/10.2298/ CICEQ150501044D

Dvořáková, M., Dostálek, P., Skulilová, Z., Jurková, M., Kellner, V., Guido, L. F. (2010). Barley and malt polyphenols and their antioxidant properties. Kvasný průmysl, 56(3), 160-163. https://doi.org/10.18832/ kp2010022

European Scientific Cooperative on Phytotherapy (2003). Matricariae flos. 2nd ed. New York: Thieme, ESCOP Monograph, pp. 312-319.

Gembala, O. (2019). Gallery of beer styles: Beers with added herbs. In: atbars.com [online]. [cit. 2020-03-20]. Available in Czech from: https://www.atbars.com/2019/07/14/galerie-pivnich-stylu-piva-s-pridavkem-bylin/

Ghorbani, A., Esmaeilizadeh, M. (2017). Pharmacological properties of Salvia officinalis and ist components. Journal of Traditional and Complementary Medicine, 7, 433-440. https://doi.org/10.1016/j.jtcme.2016.12.014

Government Decree No. 248/2018 Coll. Decree on Requirements for Beverages, Fermented Vinegar and Yeast, 4th Part - Beer and the Beer Based Beverages. Available only in Czech from: https://www.zakonyprolidi.cz/cs/2018-248\#cast4
Grochovski, D.M., Locatelli, M., Granica, S., Cacciagrano, F., Tomczyk, M. (2017). A Review on the Dietary Flavonoid Tiliroside. Comprehensive Reviews in Food Science and Food Safety, 17, 1394-1421. https://doi.org/10.1111/1541-4337.12389

Hornsey, I.S. (2003). A history of beer and brewing. The Royal Society of Chemistry, Cambridge, 760 p. ISBN 978-0-85404-630-0

Hudson, J.B. (2009). The use of herbal extracts in the control of influenza. Journal of Medicinal Plant Research, 3(13), 1189-1194. https:// academicjournals.org/article/article1380529426_Hudson.pdf

Humia, B.V., Santos, K.S., Schneider, J.K., Leal, I.L., de Abreu Barreto, G., Batista, T., Machado, B.A.S., Druzian, J.I., Krause, L.C., da Costa Mendonça, M., Padilha, F.F. (2020). Physicochemical and sensory profile of Beauregard sweet potato beer. Food Chemistry, 312, art. num. 126087. https://doi.org/10.1016/j.foodchem.2019.126087

Jahodár̆, L. (2010). Léčivé rostliny v současné medicíně. Havlíček Brain Team, Praha. ISBN 978-80-87109-22-9.

Kawa-Rygielska J., Adamenko, K., Kucharska, A.Z., Prorok, P., Piorecki, N. (2019). Physicochemical and Antioxidative Properties of Cornelian Cherry Beer. Food Chemistry, 281, 147-153. https://doi. org/10.1016/j.foodchem.2018.12.093

Klemp, F. (2016). Gruit: Just Brew It. All About Beer Magazine, 36(6). In: allaboutbeer.com [online]. [cit. 2020-03-20]. Available from: http:// allaboutbeer.com/article/homebrew-gruit-recipe/

Kosař, K., Procházka, S. et al. (2000). Technologie výroby sladu a piva, Praha. 1. Vydání Výzkumný ústav pivovarský a sladařský, 398 p. ISBN 80-902658-6-3

Lánská, D. (1999). Zelené koření. Lidové noviny, Praha, 164p. ISBN 8071063-31-2

Nerad, F. (CR) (2018). V belgickém Gentu vaří pivo bez chmele. Chutná po bylinkách a má prý povzbuzující účinky. In: radiozurnal.rozhlas. cz [online]. [cit. 2020-03-20]. Available in Czech from: https://radiozurnal.rozhlas.cz/v-belgickem-gentu-vari-pivo-bez-chmele-chutna-po-bylinkach-a-ma-pry-povzbuzujici-7180907

Olšovská,J., Matoulková, D., Čejka, J., Jurková, M. (2014). Beer and Health. Kvasný průmysl, 60 (7-8), 174-181. https://doi.org/10.18832/kp2014017

Park, S., Lee, M., Jung, S., Lee, S., Kwon, O., Kreuter, M.H., Perrinjaquet-Moccetti T., Min, B., Yun, S.H., Kim, Y. (2018). Echinacea purpurea protects against restraint stress-induced immunosuppression in BALB/c mice. Journal of Medicinal Food, 21(3), 261-268. https://doi. org/10.1089/jmf.2017.4073

Paster, N, Juven, B.J., Harshemesh, H. (1988). Antimicrobial Activity and Inhibition of Aflatoxin B1 Formation by Olive Plant Tissue Constituents. Journal of Applied Bacteriology, 64(4), 293-297. https://doi. org/10.1111/j.1365-2672.1988.tb01874.x

Petr, M. (2016). Pivní novoty: V Lobči uvařili bylinný Gruit. Chmelem šetřili. In: lidovky.cz [online]. [cit. 2020-05-26]. Available in Czech from: https://www.lidovky.cz/relax/pivo-a-pivovary/pivni-novoty-v-lobci-uvarili-bylinny-gruit-chmelem-setrili.A160923_151736_ln-pivo_mpt

Pluháčková, H., Gregor, T., Boško, R., Běláková S., Svoboda, Z. (2020). Beer fortified with selected herbal extracts. PUV 2019-36933 [CZ]. Available in Czech from: https://isdv.upv.cz/doc/FullFiles/UtilityModels/ FullDocuments/FDUM0033/uv033670.pdf

Pongoue Kamatou, G.P., Viljoen, A. (2009). A Review of the Application and Pharmacological Properties of $\alpha$-Bisabolol and $\alpha$-Bisabolol-Rich Oils. Journal of the American Oil Chemists' Society, 87(1), 1-7. https://doi.org/10.1007/s11746-009-1483-3

Poštulková, Ž. (2018). The possibilities of using of natural extracts in beer production. Thesis, MENDELU Brno, [online] [cit. 2020-07-23]. Available in Czech from: https://theses.cz/id/gs87q5/

Sohrabvandi, S., Mortazavian, A.M., Rezaei, K. (2012). Health-Related Aspects of Beer: A Review. International Journal of Food Properties, 15(2), 350373. https://doi.org/10.1080/10942912.2010.487627 
Suchý V. (1989). Farmakognosie - část speciální I. Univerzita Komenského, Bratislava. ISBN 80-22301-51-5.

Tomko J., Kresánek J., Hubík J., Suchý V., Felklová M., Sikyta B., Libický A. (1999). Farmakognózia, učebnica pre farmaceutické fakulty. Osveta, Martin, 424 p. ISBN 80-8063-014-3.

Valentová, K., Vrba, J., Bancířová, M., Ulrichová, J., Křen, V. (2014). Isoquercitrin: pharmacology, toxicology, and metabolism. Food and Chemical Toxicology, 68, 267-282. https://doi.org/10.1016/j.fct.2014.03.018

Vimalanthan, S., Arnason, J.T., Hudson, J.B. (2009). Anti-inflammatory activities of Echinacea extracts do not correlate with traditional marker components. Pharmaceutical Biology, 47(5), 430-435. https:// doi.org/10.1080/13880200902800204

Wannenmacher, J., Gastl, M., Becker, T. (2018) Phenolic Substances in Beer: Structural Diversity, Reactive Potential and Relevance for Brewing Process and Beer Quality. Comprehensive Reviews in Food Science and Food Safety, 17(4), 953-988. https://doi.org/10.1111/1541-4337.12352
Zapata, P., Martínez Esplá, A., Gironés-Vilaplana, A., Santos-Lax, D., Noguera-Artiga, L., Carbonell-Barachina, A.A. (2019). Phenolic, volatile and sensory profiles of beer enriched by macerating quince fruits. LWT- Food Science and Technology, 103, 139-146. https:// doi.org/10.1016/j.lwt.2019.01.002

Zhao, Y., Wang, J., Ballevre, O., Luo, H., Zhang, W. (2011). Antihypertensive effects and mechanisms of chlorogenic acids. Hypertension Research, 35(4), 370-374. https://doi.org/10.1038/hr.2011.195 